\title{
Share portfolio advisory: Use of the Markowitz method to optimize the risk/return ratio in individual investor shares portfolio
}

\author{
Assessoria em carteira de ações: Uso do método de Markowitz para otimização da relação risco \\ retorno em portfólio de ações de investidores pessoa física \\ Asesoramiento en cartera de renta variable: Utilización Del método de Markowitz para la
}

optimización de la relación riesgo-retorno en carteras de renta variable de inversores individuales

Received: 01/19/2022 | Reviewed: 01/21/2022 | Accept: 01/22/2022 | Published: 01/23/2022

\author{
João José de Melo Neto \\ ORCID: https://orcid.org/0000-0002-0769-6579 \\ Universidade Federal de Campina Grande, Brazil \\ E-mail: Joaojmneto@ hotmail.com \\ Isabel Lausanne Fontgalland \\ ORCID: https://orcid.org/0000-0002-0087-2840 \\ Universidade Federal de Campina Grande, Brazil \\ E-mail: lausannef@yahoo.fr
}

\begin{abstract}
With the growing development of the Brazilian financial market, the interest of small investors was visible, from the year 2019 and until june 2020 the entry of individual investors in the stock exchange had a growth of $174.7 \%$ reaching $2,824,239$ people according to B3. Despite this significant number, only $3 \%$ of the population that has some investment product owns shares of publicly traded companies, given this information is really the niche market that can be exploited. In most cases this small percentage is due to the profile of the Brazilian investor, which can be termed as conservative. Even investors who own a stock portfolio have a low value intended for this type of capital market product. This fear can be attributed to the lack of time to study the market and even by not having knowledge of it, another point that we have to take into account is the emotional and psychological insecurity of gains and losses in the small investor's portfolio, tied to poor risk management. Given the scenario, we advise some stock portfolios by reducing their risks or optimizing their returns by Markowitz's method that uses statistical and rational methods. It became apparent during the study the cost benefit and assertiveness of the same. For the development of this work, the Design Thinking method was used.
\end{abstract}

Keywords: Portfolio; Markowitz; Investor.

\begin{abstract}
Resumo
Com o desenvolvimento crescente do mercado financeiro brasileiro o interesse dos pequenos investidores ficou visível, do ano de 2019 e até o mês de junho 2020 a entrada de investidores pessoa física na bolsa teve um crescimento de $174,7 \%$ chegando a 2.824.239 pessoas segundo a B3. Apesar deste número expressivo, somente $3 \%$ da população que tem algum produto de investimento possui ações de empresas de capital aberto, diante desta informação é real o nicho de mercado que pode ser explorado. Na maioria dos casos esse pequeno percentual dá-se devido ao perfil do investidor brasileiro, que pode ser denominado como conservador. Mesmo os investidores que possuem uma carteira de ações, tem um valor baixo destinado a este tipo de produto do mercado de capitais. Esse receio pode ser atribuído à falta de tempo para estudar o mercado e até mesmo por não ter conhecimento do mesmo, outro ponto que temos que levar em conta é a insegurança emocional e psicológica dos ganhos e perdas na carteira do pequeno investidor, atrelada a um gerenciamento de risco deficiente. Dado o cenário, realizamos a assessoria de algumas carteiras de ações reduzindo seus riscos ou otimizando seus retornos pelo método de Markowitz que usa métodos estatísticos e racionais. Ficou aparente durante o estudo o custo benefício e a assertividade do mesmo. Para o desenvolvimento deste trabalho foi utilizado o método de Design Thinking.
\end{abstract}

Palavras-chave: Portfólio; Markowitz; Investidor.

\section{Resumen}

Con el creciente desarrollo del mercado financiero brasileño, el interés de los pequeños inversores fue visible, desde el año 2019 y hasta junio de 2020 la entrada de inversores individuales en la bolsa de valores tuvo un crecimiento del 174,7\% alcanzando las 2.824.239 personas según B3. A pesar de este importante número, solo el 3\% de la población que tiene algún producto de inversión posee acciones de empresas que cotizan en bolsa, dado que esta información es real el nicho de mercado que se puede explotar. En la mayoría de los casos, este pequeño porcentaje se debe al perfil del inversor brasileño, que puede calificarse de conservador. Incluso los inversores que poseen una cartera de acciones 
tienen un bajo valor destinado a este tipo de producto del mercado de capitales. Este miedo se puede atribuir a la falta de tiempo para estudiar el mercado e incluso al no tener conocimiento del mismo, otro punto que tenemos que tener en cuenta es la inseguridad emocional y psicológica de ganancias y pérdidas en la cartera del pequeño inversor, ligada a una mala gestión del riesgo. Ante el escenario, aconsejamos a algunas carteras de acciones reduciendo sus riesgos y optimizando sus rentabilidades mediante el método de Markowitz que utiliza métodos estadísticos y racionales. Se hizo evidente durante el estudio el costo beneficio y la asertividad del mismo. Para el desarrollo de este trabajo se utilizó el método Design Thinking.

Palabras clave: Cartera; Markowitz; Inversor.

\section{Introduction}

Given the improvements over the years, especially at the beginning of the 21 st century in the National Financial System, especially with regard to the capital market, with the growth in the number of investors in b3 shares or other assets, Brazil became increased one the safest country and locus of protection of minority investors who are mostly individuals, and played a fundamental role in implementing the concept of Corporate Governance in publicly traded companies. The average annual growth of $6.44 \%$ between 2008 and 2018 jumped to $106.7 \%$ in 2019 and 68\% by July 2020 reaching 2,824,239 people investing in publicly traded companies (B3, 2020). This shows that investors are safer and more confident in leaving their money invested in these companies, becoming members and thus believing in the growth purpose that they propose to implement through their management policies, mission, objectives and values.

However, even with a high percentage growth in recent years and currently, the Brazilian population applies little in investment products and there is still a large potential population to be an investor. According to studies by ANBIMA (2020), in 2019 only $44 \%$ of the Brazilian population, which represents 42 million people, had some type of application. Of these $44 \%$, the majority invested in savings accounts $(84.2 \%)$, followed by investment funds $(6 \%)$, private pension funds $(5 \%)$, private securities (5\%), government bonds (4\%), shares (3\%) and foreign currencies $(2 \%)$.

In this study it was also found that the majority of Brazilian individuals who have these types of financial products are conservative, because they apply only in the savings account, a product to which the lowest retonos pay among all the others listed above. And their socioeconomic profile is equally divided between men and women (50\% for each gender), has complete high school education, with an average age group of 43 years and monthly family income of R \$ 4,400.00 (ANBIMA, 2020).

Over the course of these previous two paragraphs, I wanted to reveal that there was enormous potential for the growth in the number of investors in stocks and consequently the sustainable rise of gains above the returns of other capital market products, so that there was the minimum possible risk of losses for the individual investor. In the sense that even with a growth of $106.7 \%$, only $3 \%$ of the total Brazilian population invested a part of their income in publicly traded companies in 2019 , through the stock exchange.

Finally, we will highlight the results of the rebalancing in 10 portfolios of individual investors who used our advice, with markowitz's method, comparing the gains at the end of six months with what they would have if they had continued with the same stock ratios.

\section{State of Art: Disclosure and Rebalancing Point of Markowitz Method}

The development of portfolio optimization models originates in the economic and financial area. Such models are used to assist in determining the portfolio of financial assets that presents the best risk-versus-return ratio from an investor's point of view. The main motivation for the development of these models is related to the reduction of the risk to which the investor is exposed, through the diversification or balancing of the portfolio. The concepts of this theory were initially formulated by H. Markowitz, who, when he published the article "Portfolio Selection" in 1952, instituted a new approach to 
the concept of investment risk. Contrary to the prevailing thinking at the time, that the best option for the composition of the portfolio was the concentration of investments in assets that offered the highest returns, Markowitz proposed that it would be possible to obtain more efficient combinations of resource allocation by assessing and off clearing the risk of the assets that made up the portfolio and thus structured the foundations on which the Modern Portfolio Theory was established (Almonacid, 2010).

The premises adopted by Markowitz for the construction of his theory were as follows (Sharpe et al., 1995):

(i) Investors evaluate portfolios only on the basis of the return on

expected and the standard deviation of returns in a given period;

(ii) Investors are risk averse, always choosing the portfolio of

lower risk among portfolios of the same return;

(iii) Investors are rational, always choosing the portfolio with the highest return among the portfolios of the same risk;

(iv) Individual assets are continuously divisible, enabling investors to buy fractions of assets;

(v) there is a risk-free rate at which investors can both lend and borrow;

(vi) Investors have the same opinion on the distribution of the probabilities of asset rates of return, thus having a single set of efficient portfolios;

(vii) Taxes and transaction costs are irrelevant.

Based on these assumptions, Markowitz (1952) postulated that the variables that interest the investor in the selection of a portfolio would be the expected return (or profitability) and the risk (variance of the expected returns).

According to Markowitz, an investment portfolio consists of the weighted average of the expected returns of the assets that make up the portfolio. In this way it is enough to calculate the arithmetic average of the expected returns of the weighted assets to obtain the return of the portfolio. The risk of a portfolio, according to theory, is more complex than the mere sum of the risks inherent in the assets that compose it. To estimate the size of the risk, there is a need to evaluate the correlation between the assets. The variance of the return is calculated as the difference between each return and the mean of the returns, squared and multiplied by the probability of the event occurring. According to Silva et al. (2009), "The correlation coefficient between two assets is a statistical measure that indicates the degree of linear dependence between the rates of return of these assets." Thus, the methodology proposed by Markowitz proposes that decisions related to the selection of investments be made based on the risk-return binomial. The set of portfolios whose distribution of the weight of assets presents, for each level of risk, the best possible return and, for each level of profitability, the lowest possible risk is called efficient frontier, According to Markowitz, considering the risk-return binomial, the investor should always choose one of the portfolios that make up the efficient frontier, to the detriment of any other portfolio possible to be built with the assets it selects (Almonacid, 2010).

Portfolios positioned on the efficient border are called efficient or optimal portfolios. According to Reilly (1994), the efficient portfolio is "the efficient portfolio that presents the greatest utility to the investor" and "lies at the point of tangency between the efficient frontier and the most useful curve possible".By the way we have that wallets that are outside the efficient border will be inefficient. That is, portfolios that if profitability is high this fact will result in increased risk or portfolios that if the risk is decreased this will result in a decrease in return. The efficient frontier alone enables the extraction of vast information relevant to the investor. The more parallel the efficient boundary in relation to the horizontal axis, the less it will be worth taking on the risk. On the other hand, the more ascendant the efficient border, the more risk-taking will be worth it, as it will be rewarded for the return.

It is worth mentioning that the Modern Portfolio Theory is not based so on Markowitz's Portfolio Theory, it has others important pillars: the Capital Asset Pricing Model proposed by Sharpe (1964), Lintner (1965) and Mossin (1966), the Efficient Markets Theory formulated by Fame (1970), the average absolute deviation model of Konno and Yamazaki (1991) and 
Minimax Model developed by Young (1998). There are several suggested metrics for risk representation, such as distribution variance, semivariance, mean absolute deviation, minimum distribution, Value-at-Risk (VaR) and Conditional Value-at-Risk $(\mathrm{CVaR})$, however it is important to emphasize that the cornerstone of these theories divides from Markowitz's study and is constantly in developing (Marzano, 2004).

\section{Methodology}

The characterization of the study is configured as empirical-analytical, with its approach used being identified as quantitative, using secondary data, in that a quantitative database of a given sample will be used for the purpose of to establish relationships or inferences about the operationalization of a particular fact in the science. An empirical-analytical study mainly aims at a causal relationship between variables. And validation of the scientific test is sought through tests of the instruments and degrees of in addition to the systematization of operational definitions. Quantitative research serves as a means to test objective theories, in which the relationship between variables is examined. By measuring these variables by instruments used for this, the numerical data can be analyzed by statistical procedures. (Martins, 2002; Creswell, 2010 apud. Alexandrino 2020).

We realize, through the data provided by AMBIMA and B3, that individual investors in Brazil are growing every year, but still have unprofitable investment products, and those who venture into buying shares of publicly traded companies on the stock exchange do not have sufficient technical knowledge to analyze good roles so little to make a good risk management. Not least because individual investors generally do not want or do not have time for deep and structured analyses that a stock portfolio requires. After all, for there to be above average results the investor will have to devote a lot of attention and effort (Graham, 2017).

This model also stands out for the relative simplicity of its handling and availability on any computer, since we will use the "Solver" tool present in any Office Excel package. Thus reducing the cost of the advisory service, leaving it accessible for all income ranges, especially to the $84.2 \%$ of individual investors who invest only in savings booklet.

The Portfolio Theory was developed by Harry Markowitz during his PhD at the University of Chigado, when in 1952 he published the study called "Portfolio Selection", which dealt with portfolio optimization (Souza et al, 2017). The common sense in the stock market among individuals is that asset diversification will reduce their risks, but Markowitz explains in his study that this maxim is not at all correct, as diversification will only be relevant if the correlations between stocks are low. So that when an action falls, other actions that do not correlate with it can balance this drop by reducing losses and vice versa. Thus, Markowitz defines with his theory the most efficient proportions that a portfolio should be diversified.

Also according to Souza et al (2017), the main point was whether there would be the possibility of minimizing the risks for a certain level of investor gains. Even knowing the direct relationship of the higher the risk the higher the return, it is extremely acceptable to achieve through the diversification of the correct roles with the lowest correlation between them, which proposes the theory.

The concept of risk in Markowitz's theory is extremely important, "risk is associated with the possibilities of occurrence of certain results in relation and an expected average value; is represented by [...] standard deviation and variance" (Silva, 2008). Thus, the higher the variance $\left(\sigma^{2}\right)$ and the standard deviation $(\sigma)$, the more dispersed the mean the point will be and consequently the higher the risk. 
From there, Gonçalves et al (2002) explains the basic mathematical model of theory:

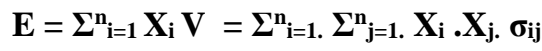

$$
\begin{aligned}
& \sum_{\mathrm{i}=1}^{\mathrm{n}_{\mathrm{i}}} \mathrm{X}_{\mathrm{i}}=1 \\
& \mathrm{X}_{\mathrm{i}} \geq 0
\end{aligned}
$$

Where: E: expected return from portfolio

V: Portfolio Variance

$\mathrm{Xi}$ : Participation of each asset

$\mu \mathrm{i}:$ Expected return of each asset

бij: Covariance between the asset pair if (i) different (j) and variance if (i) equal to (j).

Given the formulas, Markowitz can prove that although the expected return of a portfolio can be calculated using the weighted average of individual returns, this is not the case with portfolio risk characterized by variance $(\sigma 2)$ and standard deviation $(\sigma)$. They will depend on covariance between asset pairs, because "when two or more unrelated assets make up an investment portfolio, a risk lower than the weighted average of individual risks is achieved [...]" (Gonçalvas et al, 2002). And although the risk of a single share is different from the risk of this same in a stock portfolio, since now your risk will be correlated with the other (Souza et al, 2017).

With these concepts fixed, variance, covariance, standard deviation and weighted average return defined, to continue the method of our advice, through linear programming in the Solver tool we need the historical data of the quotes of the assets that make up the portfolio of the individual client, and insert the following restrictions of the model:

Individual participations $(\mathrm{Xi}) \geq 0$

The sum of individual holdings $=100 \%$ or 1

Determine the minimum rate of return of the portfolio

At the end of this process we will have the rebalancing of the portfolio, so that the risk of it is reduced to a predefined rate of return.

Finishing the explanation of the model we need to also list its limitations: the model works on an Efficient Market Hypothesis - HME, where there is symmetry of information; All decisions are based exclusively on return (Average Hope) and Risk (Standard Deviation); and there is a systematic risk, which cannot be eliminated.

However, the limitations compared to the (cost/benefit) that Markowitz's portfolio theory delivers, is almost irrelevant. Souza et al (2017) confirm this when he says that "several authors emphasize the importance of correlation (a tool used to demonstrate how two or more variables relate) in Markowitz's pioneering work [...]".

\section{Results and Discussion}

The objectives outlined for the advisory are to analyze the portfolios of clients, calculate their weighted average return in a previous period, rebalance them so that the risk is reduced, for a higher return in the future. So that their performance is subsequently evaluated, compared to performance if there was no rebalancing.

Our advisory was executed in January 2020 with ten clients who already had stock portfolios among their investments, and the gains/losses of their portfolios were measured from July 2019 to December 2019. And we rebalanced the proportions of stock amounts so that there was an increase in gains (reduction of losses) at the same level of risk. Finally, the results of the rebalanced portfolio were compared, with the result if the portfolio continued with the proportions before the advisory in June 2020. Those were the results.

The results show us that balancing was efficient in $80 \%$ of the portfolios, increasing performance and reducing risk in 
one of them.

We evaluated as viable the advice by balancing of stock portfolio by Markowitz method, because it has low cost for working with a tool available in Excel and get the result quickly, besides not requiring a physical office structure, and the advice can be done remotely in home-office. Delivering a service with $80 \%$ reliability.

Table 1: gains/losses of balanced and unbalanced portfolios.

\begin{tabular}{|c|c|c|c|c|c|}
\hline Portfolio & Stocks & $\begin{array}{c}\text { Gain/loss } \\
\text { rebalancing }\end{array}$ & $\begin{array}{c}\text { Rebalanced } \\
\text { risk }\end{array}$ & $\begin{array}{c}\text { Gain/loss without } \\
\text { change }\end{array}$ & $\begin{array}{c}\text { Risk without } \\
\text { change }\end{array}$ \\
\hline 1 & $\begin{array}{l}\text { CVC4, ITUB4, B3SA3, } \\
\text { ELET3 }\end{array}$ & $0,13 \%$ & $0,28 \%$ & $2,69 \%$ & $0,62 \%$ \\
\hline 2 & PETR3, CSNA3, VALE3, WEGE3 & $1,28 \%$ & $0,13 \%$ & $-0,26 \%$ & $0,13 \%$ \\
\hline 3 & $\begin{array}{l}\text { AZUL4, GOLL4, VVAR3, KLBN11, } \\
\text { SHOW3 }\end{array}$ & $-0,54 \%$ & $0,74 \%$ & $-1,73 \%$ & $0,74 \%$ \\
\hline 4 & $\begin{array}{l}\text { BBDC4, EMBR3, BBAS3, CVC4, } \\
\text { SHOW3 }\end{array}$ & $-4,41 \%$ & $0,72 \%$ & $-4,06 \%$ & $0,72 \%$ \\
\hline 5 & $\begin{array}{c}\text { ITUB4, B3SA3, ELET3, PETR4, } \\
\text { CSNA3 }\end{array}$ & $0,11 \%$ & $0,23 \%$ & $-0,51 \%$ & $0,23 \%$ \\
\hline 6 & $\begin{array}{c}\text { CSNA3, VALE4, WEGE3, ITSA3, } \\
\text { ENBR3 }\end{array}$ & $\mathbf{0 , 8 1 \%}$ & $0,15 \%$ & $0,31 \%$ & $0,15 \%$ \\
\hline 7 & $\begin{array}{l}\text { AZUL4, GOLL4, VVAR3, WEGE3, } \\
\text { ITSA3, ENBR3 }\end{array}$ & $\mathbf{0 , 4 0 \%}$ & $0,71 \%$ & $0,02 \%$ & $0,71 \%$ \\
\hline 8 & $\begin{array}{c}\text { PETR4, CSNA3, VALE3, KLBN11, } \\
\text { SHOW3, } \\
\text { BBDC4 }\end{array}$ & $-0,88 \%$ & $0,44 \%$ & $-0,92 \%$ & $0,44 \%$ \\
\hline 9 & $\begin{array}{c}\text { EMBR3, BBAS3, CVC4, ITUB4, } \\
\text { B3SA3, ELET3, } \\
\text { PETR4 }\end{array}$ & $-1,45 \%$ & $0,50 \%$ & $-2,07 \%$ & $0,50 \%$ \\
\hline 10 & $\begin{array}{c}\text { CVC4, ITUB4, WEGE3, VVAR3, } \\
\text { ITUB4, B3SA3, ELET3, KLBN11, } \\
\text { SHOW3 }\end{array}$ & $0,49 \%$ & $0,81 \%$ & $0,11 \%$ & $0,81 \%$ \\
\hline
\end{tabular}

Source: Authors.

We emphasize here that gains in the stock market are not guaranteed, also that there are systematic risks, the advent of COVID-19 is an example, which brought down the world stock exchanges without any relation to the market, unexpectedly. It is necessary to note that the investor profile is an important factor for the maintenance of the investment. A conservative investor would hardly bear to watch his capital reduce by $10 \%, 20 \%, 30 \%$. Even an investor with a bold profile should have portfolio protection mechanisms, such as hedge funds, foreign currencies, among others (Souza, 2021).

It is believe that to propose a better service we have to tie to the mathematical model of proportion of shares, an analysis of the fundamentals of companies in the open market, looking for the most solid and constant to achieve an even more satisfactory result. This work contributed to the expansion of the debates on sustainability, enabling (i) to understand the main subthemes associated with portfolio theory analysis related to Brazilian actions; (ii) to highlight ordering landmarks that can be used in the application of models; (iii) submit gaps found in the literature on the use of Markowitz's methods, sectors, indicators and other elements considered in these applications. In addition, it offers an approach to measuring risk mitigation that allows to smooth the effects of compensation between aggregate criteria, i.e. reducing the possibility that a low performance in a criterion is compensated by a good one. The proposed model can be applied by managers in the performance evaluations of portfolios, specific companies, institutional managers explore the specificities of the sectors and outline performance strategies, by researchers and other actors.

\section{Conclusion}

Considering that our study aims to use a new product, more practical and low cost, to deliver more reliable results in a market of high uncertainty rate, I chose the method if Design Thinking. Although Markowitz's portfolio theory dates back to 
the 1950s, in Brazil this technique is little used for the improvement of portfolios and its implementation in financial advisory can be considered an innovation in the country.

Because of this we confirm the development of our project through Desing Thinking, because "it is a useful tool that applies creative and critical thinking to understand, visualize, and describe complex problems [...], and then develop practical approaches to solve it" (Cardon, 2010 apud Bonini; Sbragia, 2011), also according to Brow (2009) cited by Bonini and Sbragia (2011) the goal is to unveil the customer's need, evaluate technologically viable solutions and develop a business that brings value to the consumer and the market.

Figure 1: Design through Desing Thinking.

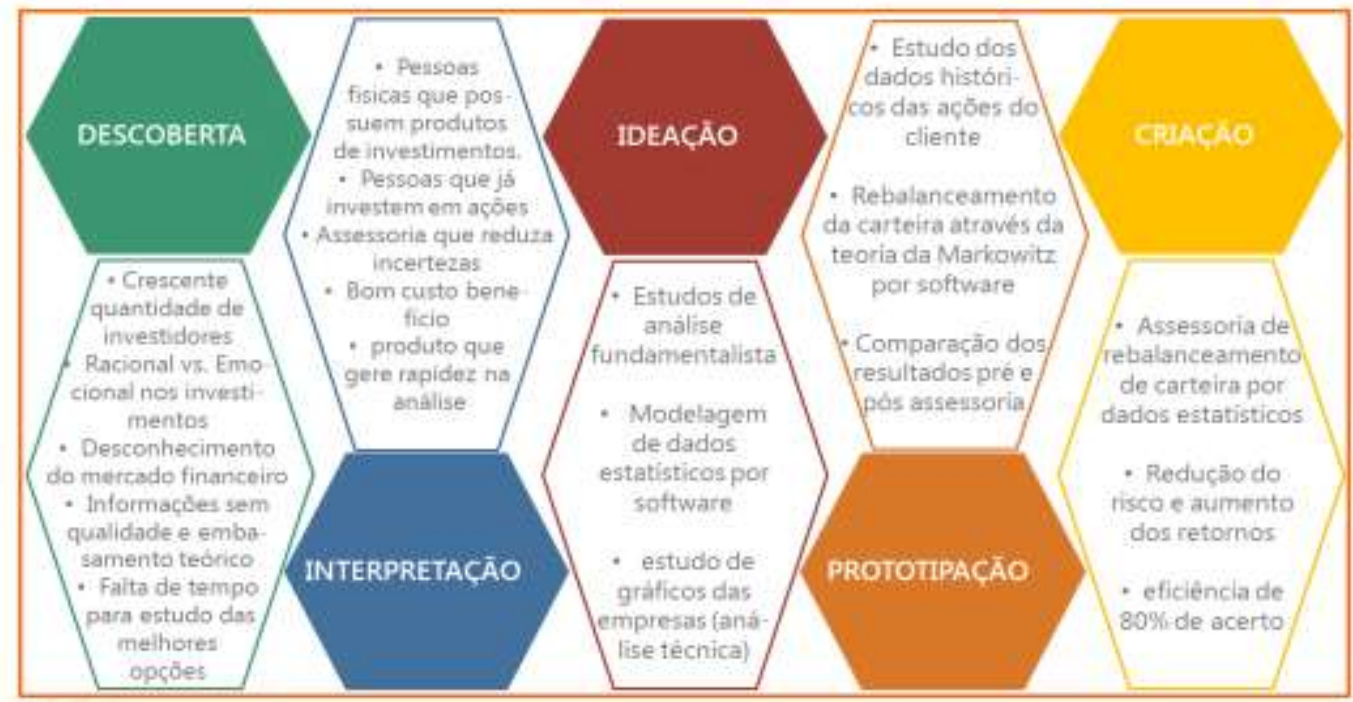

Source: Authors.

Limitations to the study: we found that it is not possible to guarantee that action selection tools choose portfolios with above the market average, but the Efficient Portfolio Stake was effective in exposing the investor to lower risk when compared to competing portfolios.

For future work we suggest the realization of the Markowitz method in a larger number of stock portfolios, in order to create robustness in the reliability of the sample of the individual investor population. We also suggest the insertion in the portfolios of other variable income products such as Brazilian depositary receipts - BDR and Exchange Traded Funds - ETF in order to reach the essential objective of the theory that is to reduce risk. And finally, we also suggest balancing portfolios according to the other theories that were explained in section 2 of this article and compare results between them.

\section{References}

AMBIMA (2020). Raio X do Investidor 2020. https://www.anbima. com.br/pt_br/especial/raio-X-do-investidor-2020.htm.

Alexandrino, T. C. (2020). Análise da relação entre os indicadores de desempenho sustentável (ESG) e desempenho econômico-financeiro das empresas listadas na B3. Dissertação (Mestrado em ciências contábeis) - Universidade Federal de Pernambuco, Recife.

Almonacid, G. A.(2010). Aplicabilidade da Teoria de Markowitz para Investimentos em Ativos do Real Estate: Estudo de Caso de uma Carteira Mista. Monografia - Escola Politécnica, Universidade de São Paulo, São Paulo.

Araújo, A. C. \& Montini, A. A.(2011). Teoria do Portfólio: Comparações Entre Modelos Alternativos Para Alocação de Recursos em Ativos de Risco. In: EnANPAD 2011. 09, 2011. Rio de Janeiro RJ. Anais[...].

Assaf Neto, A. (2012). Finanças corporativas e valor. (6a ed.), Atlas.

B3 (2020). Histórico de Pessoas Físicas. http://www.b3.com.br/pt_br/market-data-e-indices/servicos-de-dados/market-data/consultas/mercado-a-vista /historico-pessoas-fisicas. 
Research, Society and Development, v. 11, n. 2, e26011225921, 2022

(CC BY 4.0) | ISSN 2525-3409 | DOI: http://dx.doi.org/10.33448/rsd-v11i2.25921

B3(2020). índices de sustentabilidade. http://www.b3.com.br/pt_br/market-data-e-indices/.

Bezerra, P. R. S. (2021). Proposição de um novo modelo para avaliar a sustentabilidade empresarial. Dissertação de Mestrado. Universidade Federal de Campina Grande, Campina Grande.

Boaventura, J. M. G.; Cardoso, F. R.; Silva, E. S. \& Silva, R. S. (2009) Teoria dos stakeholders e teoria da firma: um estudo sobre a hierarquização das funções-objetivo em empresas brasileiras. Revista Brasileira de Gestão de Negócios - RBGN, São Paulo, 11 (32), 289-307.

Bonini, L. A \& Sbragia, R. (2011). O Modelo de Design Thinking como Indutor da Inovação nas Empresas: Um Estudo Empírico. Revista de Gestão e Projetos, 2 (1), 03 - 25.

Cavalcanti, F., \& Misumi, J.Y. (2001). Mercado de capitais. Campus.

Douglas, M. (2015). Tranding: Atitude Mental do Trader de Sucesso. (3a ed.), Bookout.

Fávero, L. P. L. \& Belfiore, P. P. (2017). Manual de análise de dados: estatística e modelagem multivariada com excel, SPSS e stata. Elsevier.

Fortuna, E. (2008). Mercado Financeiro. (17a ed.), Qualitymark.

Gonçalves Jr., C. \& Pamplona, E. O.; Motevech, J. A. (2001). Seleção de Carteiras Através do Modelo de Markowitz Para Pequenos Investidores (Com o Uso de Planilhas Eletrônicas). In: IX SIMPEP. 10, 2002. Bauru-SP. Anais[...]. Bauru-SP.

Gonzales, R. S. (2012). Governança Corporativa: O Poder da Transformação das Empresas. Trevizan Editora.

Graham, B. (2017). O Investidor Inteligente. Harper Collins Brasil.

Levine, D. M. et al. (2011). Estatística: Teoria e Aplicações. LTC.

Marzano, L. G. B. (2004). Otimização de portfólio de contratos de energia em sistemas hidrotérmicos com despacho centralizado. Tese (doutorado em engenharia elétrica) Pontifícia Universidade Catolica.

Pinheiro, J. L. (2019). Mercado de Capitais. (9a ed.), Atlas.

Reilly, F. K. (1994). Investment Analysis and Portfolio Management. (4a ed.), Fort Worth: Harcourt Brace.

Sharpe, W. F.; Alexander, G. J. \& Bailey, J. V. (1995). Investments. (5a ed.), New Jersey: Prentice Hall.

Silva, C. A. G. (2008). Gerenciamento de Risco de Carteira Otimizada. In: XXVIII ENEGEP. 10, 2008. Rio de Janeiro RJ. Anais[...].

Souza, L. C. et al. (2017). Otimização de Carteira de Investimentos: Um Estudo Com Ativos do Ibovespa. Revista de Gestão Finanças e Contabilidade, 7 (3), 201-213.

Souza, A. C. S. (2021). Análise da relação risco-retorno dos principais métodos de tomada de decisão ao alcance de investidores pessoa física na negociação de ações de empresas do mercado financeiro brasileiro . TCC (Graduação em Ciências Econômicas). Universidade Estadual Paulista (UNESP), Araraquara. 